\title{
Mobile Money, More Freedom? The Impact of M-PESA's Network Power on Development as Freedom
}

\author{
KEVIN P. DONOVAN ${ }^{1}$ \\ University of Cape Town
}

\begin{abstract}
The role of ICTs in development is contested between those who believe they will facilitate human development and those who believe they are, at most, impotent, and at worst, counterproductive. This article uses an examination of M-PESA, a large-scale mobile financial service in Kenya, to argue that the impact of ICTs on development as freedom differs with both the specific conceptualization of freedom used, and the institutional arrangement of the technology in question. The article's novel conceptual model links the adoption of mobile money to its impact, suggesting that the dominant individualistic and instrumental approaches to ICT4D overlook the ways in which power and domination function alongside freedom when these factors are considered relationally and substantively. I demonstrate that the internal plurality of the concept of freedom leads to both new forms of empowerment, but also to limitations on choice and new forms of dominance. In closing, I suggest institutional and technological arrangements that are most likely to maximize the development potential of mobile money.
\end{abstract}

\section{Introduction}

In an increasing number of developing countries, millions of poor people are using basic mobile phones to transfer money; pay for goods; and access sophisticated financial services, such as credit, insurance, and savings accounts (Donovan, 2012). As "mobile money" becomes commonplace, research is shifting from studying design and adoption to assessing impact (Donner \& Tellez, 2008). Although impact assessment remains nascent, that which does exist has been criticized for lacking rigorous conceptual or theoretical approaches, and instead, relying heavily on practitioner surveys, rather than academic research (Duncombe \& Boateng, 2009).

\footnotetext{
${ }^{1}$ I'm grateful for the comments from Carl Dahlman, Jonathan Donner, Tim Kelly, Bill Maurer, Charles Weiss, and two anonymous reviewers. The research was supported in part by a grant from Georgetown University's Science, Technology \& International Affairs program, by the Institute for Money, Technology \& Financial Inclusion at UC Irvine, and by a Fulbright Fellowship.
}

Kevin P. Donovan: kevin.donovan@uct.ac.za

Date submitted: $12-02-23$

Copyright (c) 2012 (Kevin P. Donovan). Licensed under the Creative Commons Attribution Non-commercial No Derivatives (by-nc-nd). Available at http://ijoc.org. 
This study is an effort to move past a rather narrow, "economistic" approach to impact assessment that typically privileges quantifiable evidence, such as cost reduction, adoption rates, or job creation. It situates the impact of the most successful mobile money service-Kenya's M-PESA-within interrelated theories of freedom, most clearly Amartya Sen's (1999) capability approach, which posits "development as freedom." The tensions between ICTs and freedom that it documents contribute to and challenge a growing literature on the relationship between ICTs and the capabilities approach (Gigler, 2004; Kleine, 2011; Smith, Spence, \& Rashid 2011; Zheng, 2007).

Doing so also connects the burgeoning community of "mobile money intellectuals" (Maurer, 2011) to the ongoing debate on the relationship between technology and society. As Misa (1994) notes, this debate has largely been split between those who study "broad causal patterns" (macro-level), and those who examine a "tightly focused story [of] complexity and diversity" (micro-level). He argues that understanding the complicated interplay between technology and society requires moving beyond, or, more accurately, between the macro and micro framings. In his judgment, meso-level approaches that examine the actors, institutions, and processes that intermediate between micro (e.g., firm, individual) and macro (e.g., market, state) constitute the best method for resolving such disputes as those plaguing assessments of ICT and development. Similarly, Brey (2003) writes of "specification" as a method where an abstract phenomenon (e.g., the interplay between ICT and development) is examined through a study of a specific case (e.g., M-PESA; see also Mansell, 2002).

This article takes its methodological cue from these authors, focusing on a mobile financial service that mediates between individual livelihoods and national development trends. It begins by utilizing David Singh Grewal's (2008) structuration theory for the adoption of network standards to organize the extensive literature on the adoption of M-PESA. As Grewal argues, standards grow with a unique form of power that he deems "network power." After documenting that, indeed, this phenomenon is operating in Kenya, the article evaluates its impact on the liberties of users. Doing so demonstrates that networked technologies have complicated-and at times, contradictory-impacts on development, largely depending on how freedom is specifically defined. This article concludes with suggestions for potential practices to maximize the development impact of M-PESA, and with directions for future inquiry. Both the methodological and conceptual approaches are offered as novel directions for future ICT4D research.

\section{M-PESA as Network Standard}

As of late 2011, more than 14 million Kenyans were registered users of M-PESA, a popular mobile money service of a local mobile network operator, Safaricom. M-PESA is an application that resides on the SIM card of a mobile phone. Users may freely register at a network of more than 20,000 "agents" who also transfer cash into electronic value and vice versa for M-PESA users. A typical user might load a few thousand Kenyan shillings into their personal digital wallet before sending that value to a distant family member, who would then be able to "withdraw" the money from another agent, with a transaction fee being deducted in the process. With its growth, a significant number of businesses-both existing and new-have begun to adopt the service, allowing customers to perform a variety of activities via mobile, such as paying for goods and services, receiving insurance payouts, or opening affordable bank accounts 
(Kendall, Maurer, Machoka, \& Veniard, 2011). In fact, M-PESA is one of the most popular network technology standards in Kenya, uniting agents, customers, and businesses.

Although the adoption and diffusion of a technology is always a complex phenomenon (Rogers, 2003), network standards do have common characteristics. First, network standards such as M-PESA realize positive externalities: The network standard becomes more valuable with more scale. Factors associated with the growth of M-PESA are important insofar as they advance the network effects accumulating to the M-PESA standard. Second, growing standards tend to "eliminate alternative standards that might have been freely chosen" (Grewal, 2008, p. 26). As new users join a network, the network they leave becomes less valuable, sometimes being caught in a negative feedback loop. This phenomenon has been identified in various information-based contexts (Shapiro \& Varian, 1999), including those of operating systems, social networks, and the Internet more generally (boyd, 2010).

"Network power" is the combination of 1) network effects and 2) the subsequent elimination of alternative standards (Grewal, 2008). In his book detailing the phenomenon, Grewal explores how the choice between competing standards comes laden with implications for power, freedom, and individual choice. Although technical design differences do influence the process, "network power" is a broader argument about the social dynamics of standardization, from legal to technical codes and beyond. Human interest in social coordination is the primary driver behind the will to standardize, but because a growing standard can be driven by a positive feedback loop in which its value increases to the detriment of other standards, some networks will be deserted, while others become dominant. After all, who still uses a fax machine?

\section{The Adoption of M-PESA}

Grewal's book also provides a unique framework that distills the drivers of standards adoption into three categories: reason, force, and chance. After briefly defining the terms, this section explains how M-PESA was adopted at various times due to the interplay of these factors.

In the adoption of a standard, reason refers to the capacity of a standard to satisfy better than alternatives, to "the goals that an agent has when entering into a cooperative agreement" $(2008$, p. 32). Given a choice of standards by which to communicate with others, people will use logic to consider and make judgments about their options. Their rationale can either be intrinsic, meaning that it derives from characteristics inherent to the standard, or extrinsic, meaning that its attractiveness comes from the size of the network it unites. With all standards, intrinsic reasons for adoption will be relatively more important at earlier stages, when the network is small, but as the network grows, extrinsic reasons will supersede those inherent to the standard.

Grewal also separates force into two varieties. Direct force involves imposing "costs," such as violence or other punishments on those who fail to adopt a given standard. Direct force may also involve "denying benefits unrelated to the immediate standard-governed activity" (ibid., p. 36). In this case, adoption is not driven by reason, but by direct coercion. Indirect force, on the other hand, is the opportunity cost that arises from non-membership in a network. In this incarnation, compulsion is less 
directed; instead, it emerges from the adoption by others of a standard and the desire to coordinate with them.

The final factor in the adoption of a standard is chance, defined as "accidental convergence" on a standard (ibid., p. 37). If chance is particularly potent, a standard may be adopted that is purely arbitrary; more likely, though, chance will be just a part of a standard's adoption, interacting with reason and force.

Table 1. Grewal's 2008 Framework.

\begin{tabular}{|c|c|c|c|c|}
\hline \multicolumn{5}{|c|}{ Grewal's (2008) Framework for the Adoption of a Standard } \\
\hline \multicolumn{2}{|c|}{ REASON } & \multicolumn{2}{|c|}{ FORCE } & CHANCE \\
\hline Intrinsic & Extrinsic & Direct & Indirect & - \\
\hline
\end{tabular}

\section{Intrinsic Reason}

Because M-PESA is relatively new, intrinsic reasons to adopt the standard have been preeminent. Mobile phones and services are generally considered appropriate technologies for developing countries (Harvey \& Sturges, 2010) due to low cost, ease of use, and flexible subscription plans (Andjelkovic. 2010). This makes them particularly apt to bridge the digital divide, a phenomenon that van Dijk and Hacker (2005) argue occurs at four levels-psychological, material, skills, and usage-each of which MPESA has largely overcome.

Psychological barriers, such as apathy or fear of a technology, were largely nonissues for M-PESA because it built on existing goodwill toward Safaricom, and because it utilized consistent branding, rigorous agent training, and regular auditing (Mas \& Radcliffe, 2010). Trust was additionally built through the use of immediate transaction confirmations via SMS, as well as paper and digital bookkeeping (Mas \& Morawczynski, 2009). Similarly, material divides were minimized through providing a free SIM card compatible with basic mobile phones (Hughes \& Lonie, 2007), making registration free and simple (Haas, Plyler, \& Nagarajan, 2010), not requiring a minimum balance (Mas \& Radcliffe, 2010), and allowing MPESA users to send money to non-users who could still redeem it for cash at an agent (Mas \& Ng'weno, 2010). Also important, M-PESA is significantly cheaper than alternative systems (McKay \& Pickens, 2010). A potential skills divide has also been curbed through modeling the system off existing popular uses like SMS, and also through the availability of agents to provide assistance.

Undoubtedly, the most important way in which M-PESA was adopted was by positioning it to meet a significant existing need in Kenya, namely the domestic remittance market. Like many countries in Africa, Kenya has experienced rapid urbanization in recent decades, but migrants maintain strong ties to 
rural areas through remittances of both cash and in-kind transfers (Gugler, 2002). A national survey in 2007 found that $33.4 \%$ of respondents remitted domestically, with most of them sending cash via friends and family or other informal mechanisms (FinAccess, 2007; Morawczynski, 2008). However, these systems were considered risky and expensive, with one surveying noting "service gaps, inefficiencies, and unmet demand" (Kabbucho, Sander, \& Mukwana, 2003).

M-PESA was a faster, cheaper, and more reliable way to remit. So when M-PESA was launched, it was rapidly adopted for that purpose. According to fieldwork conducted in Kibera in 2007, only months after the launch of M-PESA, the system was already used by a majority of surveyed residents to remit money back to rural homelands (Morawczynski, 2008). Users particularly valued the convenience and security of M-PESA (Haas et al., 2010).

\section{Extrinsic Reason and Indirect Force}

Despite the strong evidence of intrinsic reasons to adopt M-PESA, inherent qualities are far from deterministic, and M-PESA has had its share of difficulties (indeed, similar systems have struggled in similar countries; see Davidson \& Penicaud, 2012). Among its shortcomings are fees that effectively prohibit small transactions (Comninos, Esselaar, \& Ndiwalana, 2008; Roodman, 2010), regulations barring large transactions (Haas et al., 2010), lack of universal mobile phone access (Jack \& Suri, 2011a), difficulties for agents managing liquidity and raising start-up capital (Eijkman, Kendall, \& Mas, 2009), and complications for third-party organizations and firms seeking to integrate with it (Sadana et al., 2011). To this day, network outages are a frequent complaint among Kenyans.

In addition to these shortcomings, as with other new standards, Safaricom faced adverse network effects at the launch of M-PESA, and it needed to attract both customers and agents simultaneously. However, M-PESA had a form of built-in network power because its provider, Safaricom, has a dominant market position in Kenya, with $68 \%$ of mobile subscribers (Communications Commission of Kenya, 2011). Because infrastructure like M-PESA is often embedded in other systems and built upon an installed base (Star, 1999), in this regard, M-PESA is fairly typical. Yet any consideration of the rapid uptake of M-PESA needs to start with this fact.

Safaricom also took steps to encourage additional network power. First, M-PESA encouraged scale through its fee structure. Unregistered M-PESA users may receive money without cost to them; however, sending money to non-users incurs a higher cost to the sender than if the recipient had been registered for M-PESA. Like other instances of differential pricing (Shapiro \& Varian, 1999), this extends de facto access to a portion of M-PESA (the agent-based cash withdrawals) to a much larger population than would otherwise be possible (in effect, everyone with access to a mobile phone). Moreover, by imposing a higher fee on the sender, Safaricom provides an incentive for users to encourage their recipients to sign up for $M-P E S A$. The evidence shows that "many rural cash recipients reported that their urban relatives, the senders, persuaded them to sign up with M-PESA" (Mas \& Morawczynski, 2009, p. 87). Other surveys confirm that individuals perceive M-PESA as a means to transact with a wider network of individuals than would otherwise be possible (Haas et al., 2010). 
The M-PESA agent network has also been driven by network power. At the time of its launch, the large existing network of Safaricom airtime retail agents provided existing scale to the new standard, giving it built-in network power. This was complemented by the number of customers M-PESA mobilized, making M-PESA agency "a viable stand-alone business" (Mas \& Ng'weno, 2010). The fact that Safaricom has had to carefully manage the number of licensed agents to meet demand while ensuring the agents' profitability (Mas \& Radcliffe, 2010) further suggests a positive feedback loop-the first component of network power. Additionally, this profitability can be interpretted from its flip side: the opportunity cost of retailers not joining the standard, or what Grewal calls indirect force. In addition to thousands of smallscale retailers adding M-PESA agency to their services, as of early 2011, around 425 organizations, ranging from government agencies to retailers and banks, were using M-PESA to transact with individuals on a large-scale (e.g., through bill payment or salary dispersal). Because that critical mass is unlikely to be reached by other financial providers, many organizational users are attracted to the M-PESA standard in large part because of the size of the network it unites. In short, adoption has been, and is increasingly being, driven by the size of the M-PESA network relative to alternatives.

Combined with the intrinsic advantages, these strategies rapidly drove M-PESA to an enormous scale. Although it only debuted in March 2007, by late 2008, already only $18 \%$ of nonusers in a nationally representative survey reported not knowing about M-PESA; a year later, this figure was down to 3\% (Jack \& Suri, 2011a). Within two years, it was already registering 10,000 new customers per day (Safaricom, 2009). By November 2010, M-PESA had more than 13 million registered customers (Safaricom, 2011), or nearly $60 \%$ of Kenya's population above 15 years old (CIA, 2011). This customer growth has been matched by a proliferation of M-PESA agents, who numbered more than 22,000 in November 2010.
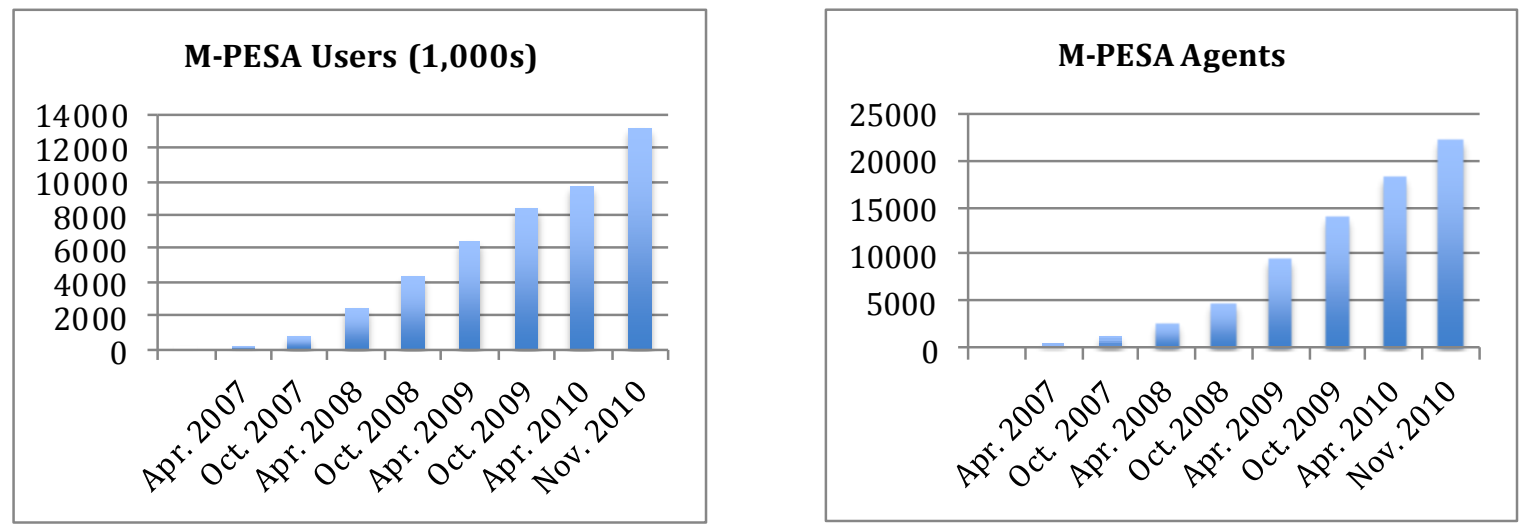

Figure 1. Growth in M-PESA users and agents.

National household surveys similarly emphasize the scale at which M-PESA operates. In late 2008, 43\% of households had an M-PESA user; a year later, that number was $70 \%$, and given the continued growth reported by Safaricom in the data above, it is likely even higher now. A similar growth 
was noted in the number of monthly transactions, which increased from 354,000 in July 2007 to 16.7 million in July 2009 (a 4,600\% increase). In that same month, the value of M-PESA transactions was $4.36 \%$ of commercial bank deposits in the country, or US\$535 million, in a country where the national GDP the year before was only US\$30.24 billion (Kimenyi \& Ndung'u, 2009).

\section{Displacement of Alternative Standards}

At some point in the past few years, M-PESA's growth has begun to display significant evidence of the second component of network power: the displacement of alternative standards. Camner, Pulver, and Sjöblom (2009) found a "massive" reduction in using hand-delivery, post office, bus travel, or courier companies for remitances after the launch of M-PESA. Similarly, the World Bank reports that "by 2009, mobile money transfer had almost entirely displaced transfers via the post office and via bus/matatu (minibus), which were previously popular methods. A substantial minority, however, still send transfers via friends and family" (2010, p. 21). In 2006, prior to the launch of M-PESA, money was sent by friend or family $(50 \%)$, bus $(29 \%)$, money transfer services such as Western Union $(29 \%)$, check (9\%), direct deposit $(6 \%)$, post office money order $(4 \%)$, or some other method (2\%) (FinAccess, 2007). In only a year and a half after the launch of M-PESA, it accounted for $47 \%$ of money transmissions, followed by hand-delivery (32\%), bus (9\%), direct deposit (7\%) and other (6\%; Pulver, 2009). Meanwhile, in their more recent nationally representative surveys of M-PESA use, Jack and Suri (2011a) say that it has almost completely replaced alternative remittance channels.

Replacing alternative financial services is a stated goal of Safaricom, whose former CEO has "[joked] with the governor of the Kenyan national bank that he doesn't need to print money any more, as M-Pesa is taking over" (Joseph in Palmer, 2012). Similarly, the global association of mobile operators, the GSMA, "uses the term mobile money, recognizing that the primary purpose of mobile-enabled schemes is for cash substitution purposes" (Dermish, Kneiding, Leishman, \& Mas, 2011, p. 5). ${ }^{2}$

Observers are increasingly noting that mobile money can serve as a general purpose technology platform on which other services can develop. Mas and Radcliffe think it represents a new way to promote financial inclusion by "building the payment 'rails' on which a broader set of financial services can ride" (2010, p. 357). Indeed, the Safaricom-operated mobile money standard is increasingly being adopted for services such as interest-yielding bank accounts, customer-to-business payments (such as electricity bills or tickets), and even insurance and credit services (see Kendall et al., 2011, for a survey). Although the existing evidence on adoption of mobile money for services beyond peer-to-peer transfer is mixed (Sadana et al., 2011; Stuart \& Cohen, 2011), it is clearly not a marginal influence on the financial activities of most Kenyans.

\footnotetext{
${ }^{2}$ As discussed further below, this aligns with a growing chorus of proponents of "cashlessness" who are raising concerns about credibility and trust (Maurer, 2012) and public values beyond innovation (Donovan, 2013).
} 


\section{Network Power and Voluntariness}

Grewal (2008, p. 37) writes that "at the highest levels of network power" extrinsic reason and indirect force merge. This is a form of power because while it is reasonable "to adopt a dominant standard rather than lose access to others ... this reason dictates a selection that, while rational, is chosen under the compulsion of having no viable alternatives." So, while adopting a standard may be reasonable, it is "a matter of semantics whether we should best describe the situation as determined by "reason" or determined by 'force.'" The crux of considering network power as power "is that beyond a certain point, members of a small network are "forced" to adopt the standard of a dominant network or else face isolation." Grewal explains that there is equivalence between indirect force and extrinsic reason, and that "intrinsic reason becomes irrelevant and direct force unnecessary once a standard has surpassed a critical threshold and its continued rise is driven by network power" (ibid.) In these scenarios, users face very high costs of switching between standards, often known as "lock-in" (see also Mueller, 2010; Shapiro \& Varian, 1999).

The reduction in alternative standards is worrisome, because the mere act of choice does not entail freedom. Instead, "free choice must be defined not merely by the fact of someone's having chosen something, but by the existence of viable alternatives available to her at the time when she made her choice" (Grewal, 2008, p. 108). The existence of viable alternatives at the time of choice is what the philosopher Serena Olsaretti (2004) calls "voluntariness," as opposed to mere freedom of choice. The more viable alternatives that exist, the less force is pushing an individual toward a given option. ${ }^{3}$ Put differently, freedom to choose is insufficient compared to freedom to choose freely among acceptable alternatives.

This distinction is relevant in situations of great network power, where a standard may be adopted without "voluntariness" because a lack of viable alternatives exists. Although one still has the choice to avoid a dominant network, non-membership comes with significant costs, such as the difficulty of coordinating with those in the dominant network. Just as membership in large networks has increasing benefits, membership in small networks has increasing costs (Tongia \& Wilson, 2011). The impetus to adopt a growing standard is network power, which is a substantive check on the voluntariness of one's choice. Because the poor are usually late adopters of technology (Rogers, 2003) and have, indeed, adopted M-PESA more slowly (Jack \& Suri, 2011a), the exhaustion of alternatives through the rise of a dominant standard may even be more detrimental to them. Furthermore, as suggested below, the lack of voluntariness can lead to the dominance of a standard that may not meet the needs of users, or can have unintended consequences that cannot be avoided due to the absence of viable alternatives.

\footnotetext{
${ }^{3}$ To pick a crude example, consider being told to do something at the point of a gun; inaction remains a choice, but hardly a morally acceptable one.
} 


\section{Assessing Network Power}

The theoretical observation that the adoption of networked standards is imbued with power and a redistribution of agency is not, on its own, cause for concern. As the next section will argue, M-PESA's network power has resulted in desirable redistributions of agency, as well as more worrying ones. The key, then, is to understand the normative diversity. The benefit of Grewal's theory is to explicitly link the social dynamics of adoption with the political results. Thus, in contrast to some emerging impact assessments that focus narrowly on economic indicators (e.g., Jack \& Suri, 2011b), attending to M-PESA's network power directs attention to the concerns of Sen's capability approach.

This section highlights the diversity within the concept of "freedom," demonstrating that an unreflexive attachment to instrumental well-being may overlook less obvious ways in which M-PESA limits aspects of freedom. The aim is less to offer a conclusive causal answer (which would be premature, anyway), than it is to explore how M-PESA illustrates the importance of understanding complexity, and to move past dueling arguments of utopian and dystopian approaches to technology and society, ICTs, and capabilities. As such, its affinities are more closely linked to the tradition of interpretative sociology that emphasizes Verstehen, rather than causal explanation. As Sheila Jasanoff relates, this tradition aims "to set aside reductionist, linear accounts of some of the most significant sociopolitical transformations of late modernity in favor of a kind of story-telling that does justice to the ambiguity of these experiences, and to their richness" (2007, p. 11).

\section{Development as Freedom}

Consider a hypothetical migrant in Nairobi who wishes to send a remittance to his family in a distant village. Prior to the rise of M-PESA, this was done through a variety of means, but as detailed above, M-PESA has significantly replaced alternative means of remittance, and Kenyans report being pressured to converge on M-PESA by peers who are already users of the system (Mas \& Morawcyznski, 2009; see also Jack \& Suri, 2011a). As M-PESA has grown and replaced alternative means of remittance, the voluntariness with which our migrant chooses M-PESA has shrunk. Assessing this redistribution of power, though, requires a theory of development. As suggested, Grewal's approach is closely linked to the concerns of Amartya Sen's influential capability (or capabilities) approach. In this approach, development is considered a process of expanding the freedoms people have to lead the lives they have reason to value, that is, their "well-being" (Sen, 1999). Because he equates development with an expansion of freedom, liberty is a substantive good in itself. Additionally, however, enhanced freedom is instrumental. Specifically, Sen identifies five freedoms that are instrumental in reaching development goals. These are 1) political freedoms, 2) economic facilities, 3) social opportunities, 4) transparency guarantees, and 5) protective securities. Sen dedicates considerable time to elucidating the evidence that links these freedoms to the well-being of individuals (ibid.).

Sen's philosophy of "well-being freedom" is positioned vis-à-vis an alternative "agency freedom" that "is more general since it is not tied to any one type of aim" (i.e., well-being; Sen, 1985, p. 203). In this notion of liberty, associated most strongly with libertarian theorist Robert Nozick (1977), freedom to choose, even to one's own detriment, is more valuable than the bounded freedom to improve well-being. 
Oftentimes, these two approaches are in accord, but "the judgments of agency freedom and well-being freedom can move in contrary directions," as in situations when an individual chooses to sacrifice some or all of his well-being for the benefit of another (Sen, 1985, p. 207). In such a case, one has the expanded agency to make the altruistic choice, but one's well-being is decreased.

The reason for the existence of these two (related) notions of freedom is the internal plurality of personal freedom. Within the idea of individual freedom, there are two distinct elements: effective power and procedural control. The achievement of a goal generally requires control over the process (i.e., the manner in which one will go about striving) and the power to reach that goal (i.e., the necessary capabilities and endowment to succeed). In an ideal world, free individuals would have power and control, but the reality is often different, meaning that control may not lead to power, or that power may not need control (ibid.). ${ }^{4}$ Sen believes that the complexities of modern life make individualized procedural control impossible in many cases, thus differing from those who privilege agency. In this way, Smith and Seward (2009) are right to note that much of Sen's theory is sensitive to the contexts and social relations in which people are embedded, even if ultimately his theory's "ethical focus is on the individual" (see also Robeyns, 2000, 2005). However, while well-being is a valuable ethical goal, an attachment to the capability approach should not obscure the variety of ethical virtues, and scholars should seek to understand how they are influenced by new ICTs. ${ }^{5}$

Table 2. The Types of Instrumental Freedoms and Elements of Substantive Freedom.

\begin{tabular}{|l|}
\hline \multicolumn{1}{|c|}{ Development as Freedom } \\
\hline Instrumental Freedom \\
1. Political freedom \\
2. Economic facilities \\
3. Social opportunities \\
4. Transparency guarantees \\
5. Protective securities \\
\hline Substantive Freedom \\
1. Procedural control \\
2. Effective power
\end{tabular}

\footnotetext{
${ }^{4}$ As an example of the distinction, consider a comatose patient whose guardian is given two equally effective medical options, A and B. Option A will result in fewer painful side effects, but it is associated with experiments on live animals of which the patient strongly disapproves. The patient "would, in fact, agree that treatment $A$ would have been better for his well-being, but as a free agent he would have nevertheless chosen treatment B, if he were given the choice" (Sen, 1985, p. 210). A guardian who chooses option $B$ is providing effective power to the patient, even though the coma removes procedural control.

${ }^{5}$ On the multiplicity of ethical virtues, see, for example, Schneewind, 1997.
} 


\section{Impact on Instrumental Freedom}

Thus far, the impact of mobile money has been evaluated largely in terms of instrumentality, and the results have been impressive and widely documented. Economic facilities have been the most influenced, with researchers finding significant cost savings for users (Ivatury \& Pickens, 2006; McKay \& Pickens 2010); decreases in the amount of time needed to travel (Williams \& Torma, 2007); reduced risks of theft (Morawczynski, 2008), enhanced income (Morawczynski \& Pickens, 2009), especially in rural areas (Morawczynski, 2008); improved "livelihood strategies" (Morawczynski, 2009); and risk sharing to cope with shocks (Jack \& Suri, 2011b), perceptions of economic expansion, capital accumulation, and business environment improvements (Plyler, Haas, \& Nagarajan, 2010); new job opportunities (Gencer, 2011); and economic growth (World Bank, 2010).

Protective securities have also been enhanced, through better increasing the efficiency of existing social networks of support (Goodman \& Walia, 2007), reinforcing social capital (Morawczynski, 2008), improving informal risk-sharing networks (Jack \& Suri, 2011b), and reducing vulnerability during crises (Morawczynski, 2009).

Sen (2010) would agree: Writing more broadly than on just mobile money, he has stated that ICTs enhance freedom. Sen is correct that ICTs overcome limitations of space and time, and although he acknowledges the negative uses, he deems them a net positive for development. However, this literature tends to focus on the usage and effects of technology, and less on the social dynamics and contexts of that causal relationship. As others have noted, the individualist ends and instrumentalist tendencies of the capability approach can have the effect of minimizing attention to social concerns (Gore, 1997; Ibrahim, 2006; Stewart, 2005). As Smith and Seward (2009) argue, though, there is a broader awareness within the capability approach, even if its common usage is less attentive. Incorporating network power is one way to consider the "relational ontology" (ibid.) of Sen, and doing so suggests that limitations on human freedom may emerge through the diffusion of ICTs.

\section{Impact on Substantive Freedom}

To understand why, it is necessary to turn to the substantive concept of freedom, where liberty is a good unto itself. Here, the impact of M-PESA is more mixed. While effective power has been enhanced, the network power of M-PESA means that, in a wide variety of financial interactions, the procedural control of Kenyans has been diminished. The hypothetical remitter has seen a "massive" reduction in acceptable means of remittance (Camner, Pulver \& Sjöblom, 2009), with alternatives struggling to reach or maintain the scale necessary to compete sustainably (Davidson \& Penicaud, 2012). The social dynamics of standardization have led to methods like the post office or minibus being neglected (World Bank, 2010). A sure sign of Kenyans' dependence on the service is the fact that, in a nationally representative survey, $92 \%$ of users reported expecting a large and negative effect from M-PESA shutting down (Jack \& Suri, 2011a), a prospect that would hardly occur in situations with viable alternatives.

Network power has propelled M-PESA to market dominance within one of the least competitive telecommunications markets in the world (Gillet, 2011). Its scale is such that many organizations find 
they are expected to utilize it, but as one recent study of organizations using M-PESA found, there are significant costs and difficulties associated with adopting M-PESA (Sadana et al., 2011; see also Haas et al., 2010). One senior manager of a large bank in Kenya characterized Safaricom as a "bully [that] dictates all terms," who still noted that the bank feels it must join because of the amount of users and lack of alternatives. As the authors frankly note, "An estimated 75 financial institutions in Kenya are adopting the 'If you can't beat them, join them' strategy with regard to M-PESA" (Sadana et al., 2011, p. 6). This sentiment sums up the complexity of M-PESA's relationship to development as freedom: On the one hand, individuals and organizations see the value in mobile money for meeting their well-being goals (thus, the desire to "beat them"), but at the same time, the network power of M-PESA compels adoption of a single standard that is privately owned and uniquely biased ("join them").

If a standard such as M-PESA becomes so dominant that a remitter is faced with the "choice" between 1) remitting via M-PESA or 2) not remitting at all, it is a serious limitation on his substantive freedom, and the spectrum of possibilities between that extreme scenario and an ideal of unfettered choice represents a concomitant range of limitations on procedural control. If individuals and organizations continue to adopt M-PESA-driven by the combination of network effects and reduced alternatives-this limitation on the procedural control element of freedom will be replicated in fields as diverse as retail payments, salary disbursements, and business-to-business billing.

It is important to understand this limitation on procedural control as a direct result of the same transformation that has led to the celebrated expansion of instrumental freedoms. Those benefitssummarized in the previous section-are only possible at scale, meaning that Kenyans have had to converge upon a standard, a process of harmonization that is not free from force. Sen is correct to note that, in delineating between control and power, one must be careful to avoid creating too much of a binary distinction: "The well-being aspect and the agency aspect both demand attention, but they do so in different ways, and with varying relevance to different problems" (1985, p. 208) In the case of domestic remittances, the expansion of well-being freedom at the cost of choice would seem to be a positive development, but it is not without downsides.

Even if one is comfortable with the reduction in alternatives as a necessary cost of the instrumental empowerment, it is still possible to be concerned about the dominance of M-PESA. As Philip Pettit's theory of classical republicanism argues, people are free insofar as others lack the capacity to arbitrarily interfere in their affairs (Pettit, 1997). This is closely related to Sen's theory, because a lack of capabilities means people are "subject to a certain sort of exploitation and manipulation. Other things being equal, then, any improvement in their lots is bound to reduce the capacity of others to interfere more or less arbitrarily in their lives" (Pettit, 1997, pp. 127-128; see also Pettit, 2001). M-PESA has successfully surmounted traditional forms of domination, such as highway robbery of cash remittances, but in doing so, a new entity has reached the potential to exert a degree of domination. Weber (1978) may have been the first to note that domination could arise by "virtue of a constellation of interests," but Pettit sets a very high bar, skeptical even of mutually beneficial dominance. And some observers have expressed similar reservations: Zuckerman (2010) suggests that the significant revenue of Safaricom (more than US $\$ 1$ billion per annum, with nearly $10 \%$ coming from M-PESA) is problematic, and the fact 
that mobile money users both provide higher revenue and are less likely to switch to a different provider only exacerbates this type of concern.

This dominance is also meaningful because standards are not neutral. Convergence upon one standard (e.g., M-PESA) and not another (e.g., informal bus remittances) brings a concomitant privileging of certain norms and values. This is true for technological standards in general (Lessig, 2000; van Schewick, 2010), and financial ones in particular (Maurer, 2008). The biases of M-PESA are an emergent effect of its network power. Regardless of the conditions under which the choice to adopt a standard was executed, "some decisions are already made long before" a standard ever gets used (Kleine, 2011). In the case of M-PESA, the qualities that make it appealing (speed, reliability, and convenience) are not without downsides. The social context of money is highly complex and nuanced (Maurer, 2006), so technological innovation will have subtle and unpredictable implications that deserve enhanced attention.

Already, some hints of the unintended consequences are visible. In the case of M-PESA, the same instrumental benefits lauded by those claiming an increase in freedom, namely efficiency and low cost, seem to be challenging the social capital that many argue is key to development (e.g., Fukuyama, 1995). Ethnographic studies by Morawczynski $(2008,2009)$ identified strains on social capital, as M-PESA led to increased remittance solicitation and decreased rural visits, as well as to reductions in using friends and families as cash remittance intermediaries. Hughes and Lonie (2007) note that a microfinance institution that adopted mobile money early was disturbed to find that attendance at group meetings, a practice many feel is essential to microfinance's success, decreased.

The M-PESA standard is imbued with additional values. In contrast to cash's anonymity, M-PESA is personally identifiable, bringing a host of new privacy concerns to a region without much privacy protection (Makulilo, 2012). It also serves to shift responsibility for the means of exchange away from the state, raising questions about credibility that have yet to be explored at length (Maurer, 2012). One of the more important influences of the convergence upon the M-PESA standard, rather than alternatives, is the extent of (corporate) control. As with mobile networks more generally, M-PESA is relatively closed, potentially raising costs and barriers to innovation (Zuckerman, 2010). Future research should seek to understand the embedded values potentially being lost with displaced financial standards, who is affected, and to what extent those affected people have voluntary choice in the matter.

This internal conflict within the concept of freedom is not unique to M-PESA. As Sen (1985) argues, the multiplicity of actors in modern society often makes procedural control infeasible. There are simply too many moving pieces to provide individualized control, but policy or practice that allows individuals to achieve the functioning they would have chosen can enhance their freedom. Similarly, Grewal has noted that standardization is "Janus-faced, generating new forms of freedom and new problems of entanglement" (2008, p. 8). This is the experience with M-PESA: The process of development using M-PESA has generated both new forms of freedom and new problems of entanglement. The purpose of this article is not to romanticize either unencumbered choice or the situation prior to M-PESA, but rather, to argue that more careful and theoretically informed attention to the social processes of technological adoption and their collective political impact will provide a more accurate understanding of the trade-offs inherent in using networked technologies for development goals. 


\section{Maximizing the Development Potential of Mobile Money}

Despite the conflicting forms of empowerment and compulsion that arise from large-scale networked standards like M-PESA, it is possible to take steps toward minimizing the distributional concerns while maximizing the benefits. To "counter the power of a dominant standard," Grewal writes, "we need to open up access to its network in a way that does not require outsiders to abandon their standards" (ibid., p. 172). Although all network standards display a level of commonality due to the social dynamics of adoption, they do have differing properties that determine the extent to which they exhibit network power. Although this final section can only provide a preliminary overview, future research on the relationship between ICTs and development will benefit from such a framework.

Two key properties of standards are malleability and interoperability. Malleability is the extent to which a standard is "open to (piecemeal) revision" (ibid., p. 177). In the case of M-PESA, as proprietary software, it does not accept the type of tinkering and modification that characterizes such open standards as those that power the Internet (van Schewick; 2010, Zittrain, 2008). Interoperability (what Grewal calls compatibility) is the "acceptance of parallel or simultaneous standards to gain access to a given network" (2008, p. 173). Furthermore, thus far, M-PESA is not interoperable with other mobile money systems. Some forms of interoperability, such as an application programming interface (API), would allow third parties to lower the cost of adopting M-PESA, thus reducing the cost to adopters driven by its network power. Other types of interoperability, such as with other mobile money providers, are more complicated. First movers such as Safaricom are typically unwilling to interoperate their systems for fear that competitors will free-ride on their significant investment, and regulators are hesitant to enforce interoperability if it may chill the market. ${ }^{6}$ While more decentralized mobile communication methods could foster the type of innovation seen on the Internet (Zuckerman, 2010), evidence from mobile money deployments suggest that "mandated in the wrong circumstances [interoperability] could reduce the incentive for mobile operators to offer mobile money services, thus stunting the opportunity" (Bellis \& Nagel, 2009, p. 80; see also Davidson \& Leishman, 2012; Houpis \& Bellis, 2007; Kumar \& Tarazi, 2012). In this case, pursuing a reduction in network power could reduce the instrumental benefits of M-PESA.

Both of these properties of standards have affinities with the burgeoning literature advocating for "open development" (see Smith, Elder, \& Emdon, 2011). There is certainly much to agree with in this approach, not least of which are the likely reductions in cost, control, and barriers to innovation (Zuckerman, 2010, p. 102), and future work could do much to consider how various forms of openness intersect with various theories of freedom. As Kleine (2011) has noted, openness is a spectrum, not a binary; in the case of M-PESA, the standard is currently relatively closed, something which implies high costs for adopters and would-be experimenters, but prematurely requiring interoperability could undermine providers' incentives to invest in mobile money, since they would lack what Castells calls "the most crucial" form of modern power, "the ability to constitute network(s), and to program/reprogram the network(s)" (2009, p. 45).

\footnotetext{
${ }^{6}$ Competitors, on the other hand, are eager to interoperate, with Airtel Kenya proposing a clearinghouse that would connect all mobile money providers (Mark, 2011).
} 
Finally, it is worth noting that, although technical openness might propel mobile money adoption (and thus its instrumental benefits), this does not reduce the social dynamics of power in adopting a standard. Indeed, the network power of mobile money as a whole-interoperable between many providers-would actually increase, potentially challenging cash's dominance. Already, some are advocating an "anti-cash movement" (Sridharan, 2012), and major development organizations and private sector entities have formed the Better than Cash Alliance to support electronic payments, presenting cash as an anachronism: expensive to manage, easy to lose, and prone to illicit usages. Although it is generally unwise to take a teleological approach to technology (Edgerton, 2007), and it is unlikely that mobile money will wholly displace cash any time soon (Maurer, 2011), the same drivers behind M-PESA's displacement of alternative standards will become relevant for the future of cash as mobile money increases its network power, in general. If this occurs, while concerns about one dominant provider may be decreased, both the broader concerns about social compulsion to join the network and those specific to the standard's embedded values (i.e., personally identifiable) will remain relevant, even at a larger scale.

\section{Conclusion}

A straightforward question-"What is the impact of M-PESA on human freedom?"-led to a vast and variegated terrain. What was found was a diversity of implications: some empowering, some restraining. The root of much of this complexity is the paradoxical relationship of networks of social interaction with individual freedom. The need and desire to coordinate-in this case, financially-requires standardization. Following Grewal (2008), this convergence on a standard, in union with subsequent desertion of alternatives, has been identified as a form of power that acts on all Kenyans, both M-PESA users and not. However, the standardization has unified a substantial community, enhancing many Kenyans' abilities to reach their self-set goals.

This growth in well-being freedom is what Sen (2010) has in mind when he writes that mobiles are "generally freedom-enhancing." Yet for theories of freedom that favor agency rather than well-being, or that worry about the potential for interference by a dominant entity, the rise of M-PESA suggests cause for concern. The evidence that M-PESA exerts network power complicates the growing literature that celebrates ICTs as an enhancement of human freedom and capabilities. For example, Smith, Spence, and Rashid argue that "mobile phones constitute the basis for one of the greatest expansions of human capabilities in known history" (2011, p. 77). This article has demonstrated that, while largely correct from a well-being approach, when other ethical virtues are highlighted, such as procedural control or nondomination, new forms of compulsion and unfreedom exist alongside the instrumental benefits.

This relational and substantive approach to freedom follows from both the conceptual underpinnings of the study, as well as the methodological commitment to a meso-level analysis that examines the mediation between micro and macro (Misa, 1994; Brey, 2003). Although it offers no easy answers-and indeed, largely rejects binary responses to questions of empowerment-it begins to fill the gap on theoretically rich ICT4D assessments (Duncombe \& Boateng, 2009). It also suggests avenues for future research, including comparative analysis of the institutional and technological arrangements most likely to minimize network power while maximizing mobile money's benefit. Additionally, as mobile money 
begins to rival cash and other media of exchange in diverse settings, understanding the values embedded in standards and their implications for human flourishing will require sustained and interdisciplinary attention.

The perspective of development as freedom can both valorize and critique, adding necessary nuance to conversations about the relationship between ICT and development. Although most mobile money services are currently too small to exhibit the network power and domination that M-PESA does, the theories applied above-network power, development as freedom, and freedom as non-dominationcan be fruitfully applied to other networked standards. As donors, policy makers, and individuals continue to encourage and adopt ICTs, it would be responsible to do so realistically, with awareness of both the dual nature and the ways in which downsides can be minimized while benefits enhanced. 


\section{References}

Andjelkovic, M. (2010). The future is mobile. SAIS Review, 30(2), 121-133.

Bellis, J., \& Nagel, L. (2009). Interoperability of mobile money services. In Mobile money for the unbanked annual report (pp. 80-84). London: GSMA.

boyd, d. (2010). Facebook is a utility; Utilities get regulated. Apophenia. Retrieved from http://www.zephoria.org/thoughts/archives/2010/05/15/facebook-is-a-utility-utilities-getregulated.html

Brey, P. (2003). Theorizing technology and modernity. In T. Misa, P. Brey, \& A. Feenberg (Eds.), Modernity and technology, (pp. 33-71). Cambridge, MA: MIT Press.

Camner, G., \& Sjöblom, E. (2009). Can the success of M-PESA be repeated? A review of the implementations in Kenya and Tanzania. Nairobi: Valuable Bits.

Camner, G., Pulver, C., \& Sjöblom, E. (2009). What makes a successful mobile money implementation? Learnings from M-PESA in Kenya and Tanzania. London: GSMA.

Castells, M. (2009). Communication power. Oxford, UK: Oxford University Press.

CIA. (2011). Kenya statistics. CIA World Factbook. Retrieved from https://www.cia.gov/library/publications/the-world-factbook/geos/ke.html

Comninos, A., Esselaar, S., Ndiwalana, A., \& Stork C. (2008). M-banking the unbanked. Cape Town: Research ICT Africa.

Communications Commission of Kenya. (2011). Third quarterly sector statistics report. Nairobi: Communications Commission of Kenya.

Davidson, N., \& Leishman, P. (2012). The case for interoperability: Assessing the value that the interconnection of mobile money services would create for customers and operators. London: GSMA.

Davidson, N., \& Penicaud, C. (2012). State of the industry: Results from the 2011 global mobile money adoption survey. London: GSMA.

Dermish, A., Kneiding, C., Leishman, P., \& Mas, I. (2011). Branchless and mobile banking solutions for the poor: A survey of the literature. Innovations: Technology, Governance \& Globalization, 6(4), 8198. 
Donner, J., \& Tellez, C. (2008). Mobile banking and economic development: Linking adoption, impact, and use. Asian Journal of Communication, 18(4), 318-332.

Donovan, K. (2012). Mobile money and financial inclusion. In T. Kelly \& M. Minges (Eds.), Information and communication for development 2012. Washington, DC: World Bank.

Donovan, K. (in press). The responsibility of mobile money intellectuals? Information Technologies \& International Development, 9(1).

Duncombe, R., \& Boateng, R. (2009). Mobile phones and financial services in developing countries: A review of concepts, methods, issues, evidence and future research directions. Third World Quarterly, 30(7), 1237-1258.

Edgerton, D. (2007). The shock of the old: Technology and global history since 1900. Oxford, UK: Oxford University Press.

Eijkman, F., Kendall, J., \& Mas, I. (2010). Bridges to cash: The retail end of M-PESA. Savings \& Development, 34(2), 219-252.

FinAccess. (2007). Financial access in Kenya: Results of a 2006 national survey. Nairobi: FinAccess.

Fukuyama, F. (1995). Trust: The social virtues and the creation of prosperity. New York: Free Press.

Gencer, M. (2011). The mobile money movement: Catalyst to jumpstart emerging markets. Innovations: Technology, Governance, and Globalization, 6(1), 101-117.

Gigler, B. (2004). Including the excluded: Can ICTs empower poor communities? Towards an alternative evaluation framework based on the capacity approach. In 4th International Conference on the Capability Approach. Pavia, Italy: University of Pavia.

Gillet, J. (2011). Competition and concentration: The distribution of market power in the global cellular industry. London: Wireless Intelligence.

Goodman, J., \& Walia, V. (2007). Airtime transfer services in Egypt. In The transformational potential of $m$-transactions. London: Vodafone.

Gore, C. (1997). Irreducibly social goods and the informational basis of Amartya Sen's capability approach. Journal of International Development, 9(2), 235-250.

Gugler, J. (2002). The son of the hawk does not remain abroad: The urban-rural connection in Africa. African Studies Review, 45(1), 21-41. 
Grewal, D. S. (2008). Network power: The social dynamics of globalization. New Haven, CT: Yale University Press.

Haas, S., Plyler, M., \& Nagarajan, G. (2010). Outreach of M-PESA system in Kenya: Emerging trends. College Park, MD: Financial Services Assessment.

Harvey, J., \& Sturges, P. (2010). The cell phone as appropriate information technology: Evidence from The Gambia. Information Development, 26(2), 148-159.

Houpis, G., \& Bellis, J. (2007). Competition issues in the development of m-transaction schemes. In The transformational potential of m-transactions (pp. 30-36). London: Vodafone.

Hughes, N., \& Lonie, S. (2007). M-PESA: Mobile money for the "Unbanked"-Turning cellphones into 24hour tellers in Kenya. Innovations: Technology, Governance, Globalization, 2(1-2), 63-81.

Ibrahim, S. S. (2006). From individual to collective capabilities: The capability approach as a conceptual framework for self-help. Journal of Human Development, 7(3), 397-416.

Ivatury, G., \& Pickens, M. (2006). Mobile phone banking and low-income customers. Washington, DC: CGAP.

Jack, W., \& Suri, T. (2011a). Mobile money: The economics of M-PESA. Washington, DC: NBER.

Jack, W., \& Suri, T. (2011b). Risk sharing and transaction costs: Evidence from Kenya's mobile money revolution. (Working paper).

Jasanoff, S. (2007). Designs on nature: Science and democracy in Europe and the United States. Princeton: Princeton University Press.

Kabbucho, K., Sander, S., \& Mukwana, P. (2003). Passing the buck: Money transfer systems: The practice and potential for products in Kenya. Nairobi: Microsave Report.

Kendall, J., Maurer, B., Machoka, P., \& Veniard, C. (2011). An emerging platform: From money transfer system to mobile money ecosystem. Innovations: Technology, Governance, and Globalization, 6(4), 49-64.

Kimenyi, M. S., \& Ndung'u, N. S. (2009). Expanding the financial services frontier: Lessons from mobile phone banking in Kenya. Washington, DC: Brookings Institution.

Kleine, D. (2011). The capability approach and the "medium of choice": Steps towards conceptualising information and communication technologies for development. Ethics and Information Technology, 13(2), 119-130. 
Kumar, K., \& Tarazi, M. (2012). Interoperability and related issues in branchless banking and mobile money. CGAP. Retrieved from http://technology.cgap.org/2012/01/09/interoperability-andrelated-issues-in-branchless-banking-and-mobile-money

Lessig, L. (2000). Code: And other laws of cyberspace. New York: Basic Books.

Makulilo, A.B. (2012). Privacy and data protection in Africa: A state of the art. International Data Privacy Law 2(3), 163-178.

Mansell, R. (2002). From digital divides to digital entitlements in knowledge societies. Current Sociology, 50(3), 407-426.

Mark, O. (2011). Safaricom rivals target M-Pesa in fresh battle for marketshare. Mobile Money Africa. Retrieved from http://mobilemoneyafrica.com/?p=3207

Mas, I., \& Morawczynski, O. (2009). Designing mobile money services. Innovations: Technology, Governance, Globalization, 4(2), 77-91.

Mas, I., \& Ng'weno, A. (2010). Three keys to M-PESA's success: Branding, channel management and pricing. Journal of Payments Strategy and Systems, 4(4), 352-370.

Mas, I., \& Radcliffe, D. (2010). Mobile payments go viral: M-PESA in Kenya. In P. Chuhan-Pole \& M. Angwafo (Eds.) Yes Africa can: Success stories from a dynamic continent. Washington, DC: World Bank.

Maurer, B. (2006). The anthropology of money. Annual Review of Anthropology, 35, 15-36.

Maurer, B. (2008). Retail electronic payment systems for value transfer in the developing world. Irvine, CA: University of California, Irvine.

Maurer, B. (2011). Regulation as retrospective ethnography: Mobile money and the arts of cash. Banking and Finance Law Review, 21(1), 299-313.

Maurer, B. (2012). Credit slips (but should not fall). Distinktion: Scandinavian Journal of Social Theory, 112.

McKay, C., \& Pickens, M. (2010). Branchless banking 2010: Who's served? At what price? What's next? Washington, DC: CGAP.

Misa, T. (1994). Retrieving sociotechnical change from technological determinism. In M. R. Smith \& L. Marx (Eds.), Does technology drive history? (pp. 115-141). Cambridge, MA: MIT Press. 
Morawczynski, O. (2008). Surviving in the dual system: How M-PESA is fostering urban-to-rural remittances in a Kenyan slum. Proceedings of the Eighth International Conference on Human Choice and Computers (HCC8). Pretoria.

Morawczynski, O. (2009). Examining the usage and impact of transformational m-banking in Kenya. In N. Aykin (Ed.), Internationalization, design and global development (pp. 495-504). Berlin: Springer.

Morawczynski, O., \& Pickens, M. (2009). Poor people using mobile financial services: Observations on customer usage and impact from M-PESA. Washington, DC: CGAP.

Mueller, M. (2010). Networks and states: The global politics of Internet governance. Cambridge, MA: MIT Press.

Nozick, R. (1977). Anarchy, state, utopia. New York: Basic Books.

Olsaretti, S. (2004). Liberty, desert, and the market: A philosophical study. Cambridge, UK: Cambridge University Press.

Palmer, M. (2012). Finance: more flash than cash. Financial Times. Retrieved from http://www.ft.com/cms/s/0/63a21dcc-6f68-11e1-9c57-00144feab49a.html\#axzz29S80CdIM

Pettit, P. (1997). Republican political theory. In A. Vincent (Ed.) Political theory: Tradition, diversity and ideology (pp. 112-132). Cambridge, UK: Cambridge University Press.

Pettit, P. (2001). Capability and freedom: A defense of Sen. Economics and Philosophy, 17, 1-20.

Plyler, M., Haas, S., \& Nagarajan, G. (2010). Community-level economic effects of M-PESA in Kenya: Initial findings. College Park, MD: Financial Services Assessment.

Pulver, C. (2009). The performance and impact of M-PESA: Preliminary evidence from a household survey. CGAP. Retrieved from http://technology.cgap.org/technologyblog/wpcontent/uploads/2009/10/fsd_june2009_caroline_pulver.pdf

Robeyns, I. (2000). An unworkable idea or a promising alternative? Sen's capability approach reexamined. Discussion Paper 00.30. Center for Economic Studies, University of Leuven.

Robeyns, I. (2005). The capability approach: A theoretical survey. Journal of Human Development, 6(1), 93-114.

Rogers, E. M. (2003). Diffusion of innovations. New York: Free Press. 
Roodman, D. (2010). Make new media of exchange, but keep the old. Center for Global Development. Retrieved from http://blogs.cgdev.org/open_book/2010/05/make-new-currenciesbut-keep-theoldone-is-silverand-the-other-gold.php

Sadana, M., Mugweru, G., Murithi, J., Cracknell, D., \& Wright, G.A.N. (2011). Analysis of financial institutions riding the $M-P E S A$ rails. Nairobi: MicroSave.

Safaricom. (2009). M-PESA: The innovation that is changing lives of millions in Kenyans. Retrieved from http://www.safaricom.co.ke/fileadmin/M-PESA/Documents/Presentations/09.01.19\%20$\% 20$ Presentation $\% 20$ to\%20media.pdf

Safaricom. (2011). M-PESA customer and agent numbers. Retrieved from http://www.safaricom.co.ke/fileadmin/M-PESA/Documents/statistics/MPESA_Statistics_Jan2011.pdf

Schneewind, J. B. (1997). The invention of autonomy: A history of modern moral philosophy. Cambridge, UK: Cambridge University Press.

Sen, A. (1985). Well-being, agency and freedom: The Dewey lectures 1984. The Journal of Philosophy, 82(4), 169-221.

Sen, A. (1999). Development as freedom. New York: Anchor.

Sen, A. (2010). The mobile and the world. Information Technologies \& International Development, 6(SE, Harvard Forum), 1-3.

Shapiro, C., \& Varian, H. R. (1999). Information rules: A strategic guide to the network economy. Boston, MA: Harvard Business School.

Smith, M., \& Seward, C. (2009). The relational ontology of Amartya Sen's capability approach: Incorporating social and individual causes. Journal of Human Development and Capabilities: A Multi-Disciplinary Journal for People-Centered Development, 10(2), 213-235.

Smith, M., Spence, R., \& Rashid, A. (2011). Mobile phones and expanding human capabilities. Information Technologies \& International Development, 7(3), 77-88.

Smith, M., Elder, L., \& Emdon, H. (2011). Open Development: A New Theory for ICT4D. Information Technologies \& International Development, 7(1), iii-ix.

Sridharan, V. (2012). The end of money? New America Foundation. Retrieved from http://assets.newamerica.net/blogposts/2012/the_end_of_money-63808

Star, S. L. (1999). Ethnography of infrastructure. American Behavioral Scientist, 43(3), 377-391. 
Stewart, F. (2005). Groups and capabilities. Journal of Human Development, 6(2), 185-204.

Stuart, G., \& Cohen, M. (2011). Cash-in, cash-out: The role of M-PESA in the lives of low-income people. College Park, MD: Financial Services Assessment.

Tongia, R., \& Wilson III, E. J. (2011). The flip side of Metcalfe's law: Multiple and growing costs of network exclusion. International Journal of Communication, 5, 665-681.

van Dijk, J., \& Hacker, K. (2005). The digital divide as a complex and dynamic phenomenon. In Proceedings of the Annual Conference of the International Communication Association. Acapulco.

van Schewick, B. (2010). Internet architecture and innovation. Cambridge, MA: MIT Press.

Weber, M. (1978). Economy and society. Berkeley, CA: University of California Press.

Williams, H., \& Torma, M. (2007). Trust and fidelity: From "under the mattress" to the mobile phone. In The transformational potential of m-transactions (vol. 6, pp. 10-20). London: Vodafone.

World Bank. (2010). Kenya economic update: Kenya at the tipping point? Washington, DC: The World Bank.

Zheng, Y. (2007). Exploring the value of the capability approach for e-development. Paper presented at the 9th International Conference on Social Implications of Computers in Developing Countries, São Paulo.

Zittrain, J. (2008). The future of the Internet-And how to stop it. New Haven, CT: Yale University Press.

Zuckerman, E. (2010). Decentralizing the mobile phone: A second ICT4D revolution? Information Technology \& International Development, 6(SE, Harvard Forum), 99-103. 